\title{
Z. Lawrynowicz
}

University of Technology and Life Sciences, Mechanical Engineering Faculty, Department of Materials Science and Engineering, av. Kaliskiego 7, 85-789 Bydgoszcz, Poland

e-mail: lawry@utp.edu.pl

\section{AUSFERRITIC OR BAINITIC TRANSFORMATION IN ADI}

\begin{abstract}
The purpose of the present paper is to demonstrate how a thermodynamic method can be used for solving a problem of the decarburisation of bainite laths and carbon diffusion distances in the matrix of ADI. This should in principle enable to examine the partitioning of carbon from supersaturated ferrite laths into adjacent austenite and the carbon content in retained austenite using analytical method. The paper presents an investigation of the time required for the diffusion of carbon out of supersaturated laths of ferrite into the retained austenite. A consequence of the precipitation of cementite from austenite during austempering is that the growth of bainitic ferrite can continue to larger extent and that the resulting microstructure is not an ausferrite but it is a mixture of bainitic ferrite, retained austenite and carbides. In case of this microstructure the product of austempering reaction in ductile iron is rather bainite than "ausferrite".
\end{abstract}

Keywords: ausferrite, bainite transformation in ADI, carbon redistribution

\section{INTRODUCTION}

The attractive properties of ADI are related to its unique microstructure that consists of ferrite and high carbon austenite. Because of this microstructure, the product of austempering reaction in ductile iron is often referred to as "ausferrite" rather than bainite $[1,2,3]$. If ADI is held for long time periods, the high carbon austenite will eventually undergo a transformation to bainite, the two phase mixture of ferrite and carbide $\left(\alpha+\mathrm{Fe}_{3} \mathrm{C}\right)$. In order for this transformation to occur, longer periods of time are typically needed - much longer than would be economically feasible for the production of ADI. Once the ausferrite has been produced, the components are cooled to room temperature. The cooling rate will not affect the final microstructure as the carbon content of the austenite is high enough to lower the martensite start temperature to a temperature significantly below room temperature. Fig. 1 shows a schematic of the austempering process that includes the following major steps [4]:

(A to B) - Heating to the austenitising temperature

(B to $\mathrm{C}$ ) - Austenitising

(C to D) - Cooling to the austempering temperature

(D to E) - Isothermal heat treatment at the austempering temperature

(E to F) - Cooling to room temperature 


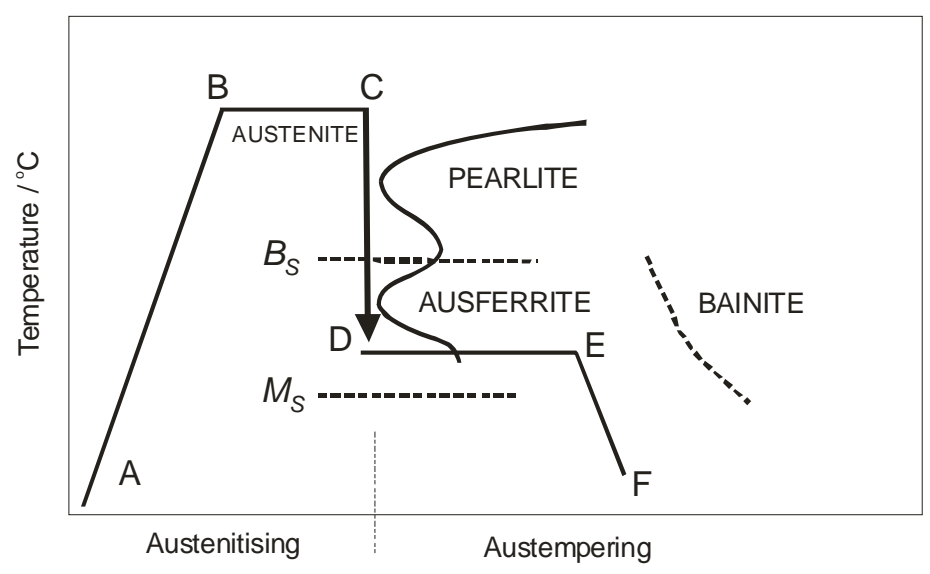

Fig. 1. Schematic of the austempering process [4]

Also graphite nodule count in ductile iron to be austempered and its uniform distribution can influence the carbon diffusion distance. Low nodule counts lead to larger spacing between the graphite nodules and larger regions of segregation. In the worst case scenario, these regions can become so heavily segregated that they do not fully transform during austempering, resulting in the formation of low carbon austenite or even martensite. Higher nodule counts will break up the segregated regions.

The purpose of the present paper is to demonstrate how a thermodynamic method can be used for solving a problem of the decarburisation of bainite laths and carbon diffusion distances in the matrix of ADI. This should in principle enable to examine the possibility of carbides precipitation in ADI.

\section{MATERIAL AND METHODS}

The chemical composition of the experimental ductile iron is listed in Table 1. The concentration of alloying elements in the matrix is obtained from the chemical analysis. Ductile iron blocks were produced in a commercial foundry furnace. The melt was poured into a standard Y block sands molds (ASTM A-395), which ensured sound castings. Specimens austenitised at $T_{\gamma}=950$ and $830^{\circ} \mathrm{C}$ for 60 minutes were rapidly transferred to a salt bath at austempering temperatures $250,300,350$ and $400^{\circ} \mathrm{C}$, held for $15,30,60,120$ and 240 minutes and then water quenched to room temperature. The microstructure of the as-cast material matrix contains $40 \%$ ferrite and $60 \%$ pearlite, however graphite nodules in material is $11.5 \%$.

Table 1. Chemical composition of ductile cast iron ADI, wt-\%

\begin{tabular}{|c|c|c|c|c|c|c|c|c|}
\hline $\mathrm{C}$ & $\mathrm{Si}$ & $\mathrm{Mn}$ & $\mathrm{P}$ & $\mathrm{S}$ & $\mathrm{Mg}$ & $\mathrm{Cr}$ & $\mathrm{Ni}$ & $\mathrm{Mo}$ \\
\hline 3.21 & 2.57 & 0.28 & 0.06 & 0.01 & 0.024 & 0.036 & 0.098 & 0.015 \\
\hline
\end{tabular}

The $X$-ray investigations were performed on the specimens heat treated after specific time of the isothermal bainite reaction at the given temperature. The total volume fraction of the 
retained austenite was measured from the integral intensity of the $(111)_{\gamma}$ and $(011)_{\alpha}$ peaks. The presence of high silicon content in ADI retards the formation of cementite in ferrite and austenite. Then, the measurements of carbon concentration in retained austenite were carried out by using $X$-ray diffraction. The carbon concentration was calculated from measured lattice parameter of the retained austenite. The $2 \theta$ values for austenite peaks were used to calculate the $d$ spacing with Bragg's law and then the lattice parameters. The lattice parameter of austenite $\left(a_{\gamma}\right)$ is related to the known relationship between the parameter and the carbon concentration [4]:

$$
a_{\gamma}(\mathrm{nm})=0.3573+0.0033 x_{\gamma}
$$

where $x_{\gamma}$ is the carbon concentration in austenite, in weight $\%$.

The matrix carbon concentration, $x_{\gamma}^{m}$, of the ductile iron was also determined experimentally with Dron 1.5 diffractometer using $C o K_{\alpha}$ radiation on specimens austenitised at 950 and $830^{\circ} \mathrm{C}$ for 60 minutes and quenched to ambient temperature. It was found that after quenching from austenitising temperature $950^{\circ} \mathrm{C}$ the calculated carbon content in matrix is $x_{\gamma}^{m}=1.044 \% \mathrm{C}$ and measured carbon content is $x_{\gamma}^{m}=1.05 \% \mathrm{C}$, and after quenching from $830^{\circ} \mathrm{C}$ the calculated carbon content in matrix is $x_{\gamma}^{m}=0.659 \% \mathrm{C}$ and measured carbon content is $x_{\gamma}^{m}=0.65 \% \mathrm{C}$, thus, the measured values were taken for further calculation.

\section{CALCULATION OF THE REDISTRIBUTION OF CARBON}

The growth of bainite is probably diffusionless but any excess carbon in the supersaturated ferrite soon afterwards partitions into the residual austenite or precipitates within bainitic ferrite in the form of carbides [5-8]. Cementite can precipitate from supersaturated bainitic ferrite and also from austenite. When the process of carbon partitioning into the residual austenite is rapid relative to that of carbide precipitation, the transformation product is called "ausferrite" or "upper bainite", whereas "lower bainite" is obtained when some of the carbon supersaturation is relieved by precipitation within the bainitic ferrite $[6,8]$. Following this a comparison between the time required to decarburise supersaturated ferrite plates with the time required to precipitate cementite within the plates appears to be a way to explaining the transition from ausferrite to upper and/or lower bainite.

The method used to calculate the time of decarburising of bainitic ferrite laths is based on the hypothesis that transformation to bainite can only occur in regions of austenite where $x_{\gamma} \leq x_{T_{0}}$, where $x_{\gamma}$ is the carbon concentration in austenite and $x_{T_{0}}$ is the carbon concentration corresponding to the $T_{0}{ }^{1}$ curve, Fig. 2.

\footnotetext{
${ }^{1}$ The $T_{0}$ temperature can be defined [9] such that stress free austenite and ferrite of the same composition (with respect to both the interstitial and the substitutional alloying elements) are in metastable equilibrium. Thus any displacive transformation involving a full supersaturation of carbon (i.e. bainitic ferrite would then inherit the carbon content of the parent austenite) can occur only below the appropriate $T_{0}$ temperature. Strain energy would have effect of shifting curve to lower carbon concentration, $T_{0}$ ' curve [10].
} 
As a lath-1 of bainitic ferrite forms it partitions its excess carbon into the retained austenite. This creates a carbon diffusion field around the lath. Another parallel lath-2 (of the same sheaf) which forms subsequently can only approach the original lath to a point where $x_{\gamma} \leq x_{T_{0}}$. The time $t_{d}$ needed to decarburise the ferrite is intuitively expected at least to be comparable to that required for a lath to complete its growth. If $t_{d}$ is small relative to the time required to relieve the carbon supersaturation by the precipitation of carbides within the ferrite, then ausferrite or upper bainite are obtained, otherwise lower bainite forms $[9,10]$. The method assumes that the interval between laths formations is larger than the time required to decarburise each lath.

Kinsman and Aaronson [11] first considered the kinetics of the partitioning of carbon from bainitic ferrite of the same composition as the parent phase. For a plate of thickness $w_{\alpha}$ the flux of carbon is defined along a coordinate $z$ normal to the $\alpha / \gamma$ interface, with origin at the interface and $z$ being positive in the austenite (Fig. 2). Lath 1 forms first and lath 2 and 3 and next is allowed to approach it to point where $x_{\gamma} \leq x_{T_{0}}$ (distance of this point from lath 1 is denoted $w_{\gamma}$ ). This is in fact the thickness of the retained austenite film. The mean thickness of the retained austenite films is almost tenfold thinner $(0.01-0.02 \mu \mathrm{m})$ than the average thickness of the bainitic ferrite laths $(\sim 0.2 \mu \mathrm{m})$.

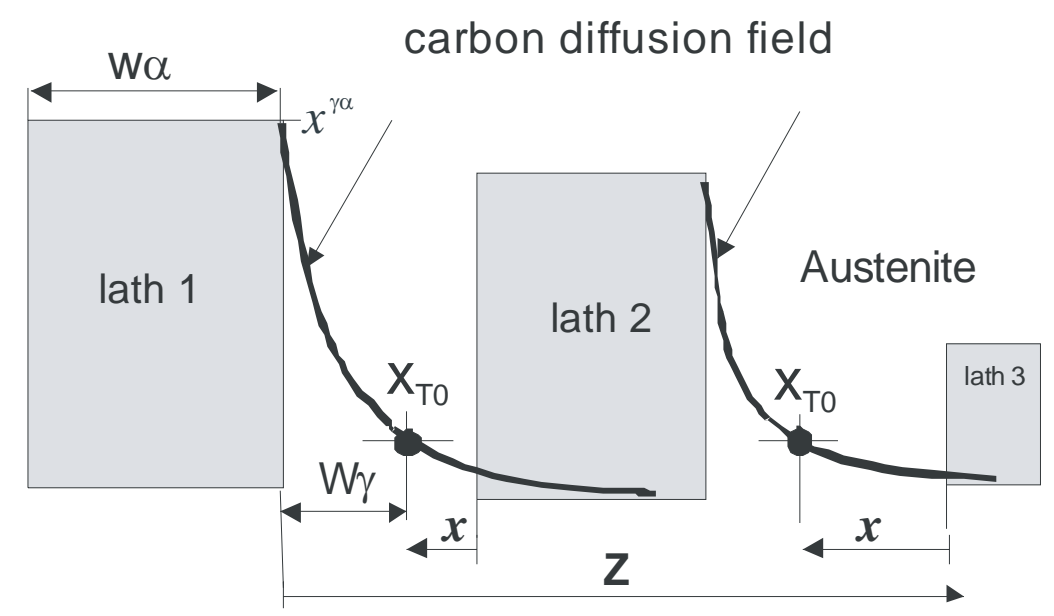

Fig. 2. Schematic diagram of method used in estimating the time of decarburising the bainitic ferrite laths 


\section{THE CALCULATION OF DECARBURISATION TIMES AND CARBON DIFFUSION DISTANCES}

Therefore the problem becomes a calculation of the sum of the decarburisation times of all bainite laths that are existing on the coordinate connecting the nearest graphite nodules (Fig. 3 and 4). The average carbon diffusion distances depend on the mean spacing among the graphite nodules. Fig. 3 shows a photomicrograph that contains graphite nodules with diverse distance among them, changing from about 150 to $50 \mu \mathrm{m}$ (marked $z_{1}$ and $z_{2}$ in Fig. 3). Thus, the average distance among nodules in examined ADI is assumed about $100 \mu \mathrm{m}$.

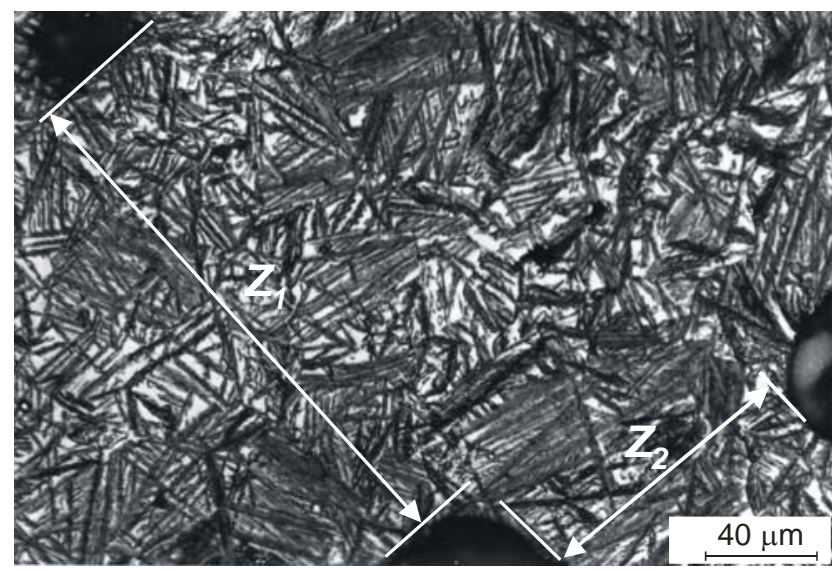

Fig. 3. Microstructure of $\mathrm{ADI}$ austenitised at $950{ }^{\circ} \mathrm{C}$ and austempered at $350{ }^{\circ} \mathrm{C}$ for 240 minutes Etched: $2 \%$ nital

Figure 4 shows a schematic of eutectic cell that contains graphite nodules and packets of bainite with different thickness of ferrite laths.
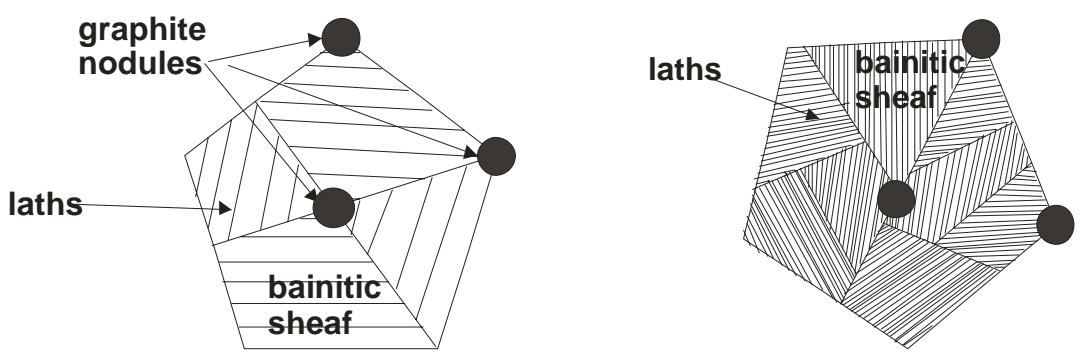

Fig. 4. Schematic of eutectic cell with different thickness of bainitic ferrite laths

The time needed to decarburise the ferrite matrix between the adjacent nodules of graphite $t_{d z}$ :

$$
t_{d z}=\sum_{i} t_{d i}
$$

where $t_{d i}$ is the time required to decarburise individual supersaturated bainitic ferrite lath of specific thickness $w_{\alpha i}$.

From the mass balance for carbon it follows that [12]: 


$$
\left(0.5 w_{\alpha}\right)\left(\bar{x}-x^{\alpha \gamma}\right)=\int_{z=0}^{\infty}\left[x_{\gamma}\left\{z, t_{d}\right\}-\bar{x}\right] d z
$$

where $\bar{x}$ is the average mole fraction of carbon in the alloy and $x^{\alpha \gamma}$ and $x^{\gamma \alpha}$ are the paraequilibrium carbon concentration in ferrite and austenite respectively. Since the diffusion rate of carbon in austenite is slower than in ferrite the rate of decarburisation will be determined by the diffusivity in the austenite and the concentration of carbon in austenite at the interface remains constant for times $0<t<t_{d}$ after which it steadily decreases as the austenite becomes homogeneous in composition. The function $x_{\gamma}$ is given by:

$$
x_{\gamma}=\bar{x}+\left(x^{\gamma \alpha}-\bar{x}\right) \operatorname{erfc}\left\{z / 2\left(D t_{d}\right)^{0.5}\right\}
$$

This assumes that for $t<t_{d}$, the concentration of carbon in the austenite at the interface is given by $x^{\gamma \alpha}$.

The diffusion coefficient of carbon in austenite $D\{x\}$, is very sensitive to the carbon concentration and this has to be taken into account in treating the large concentration gradients that develop in the austenite. It is clearly necessary to know $D\{x\}$ at least over a range $\bar{x} \rightarrow x^{\gamma \alpha}$, although experimental determinations of $D\{x\}$ do not extent beyond $x=0.06$. The value of $D$ was calculated as discussed in Ref. [13]. The good approximation of the dependent diffusivity of carbon in austenite can be a weighted average diffusivity $\bar{D}$ [14]. Taking into account carbon concentration gradients it has been demonstrated that for most purposes a weighted average diffusivity $\bar{D}$ can adequately represent the effective diffusivity of carbon [14-16]. Weighted average diffusivity $\bar{D}$ is calculated by considering the carbon concentration profile in front of the moving ferrite interface as given by the following equation:

$$
\bar{D}=\int_{\bar{x}}^{x^{\gamma \alpha}} \frac{D d x}{\left(x^{\gamma \alpha}-\bar{x}\right)}
$$

On carrying the integration, the time required to decarburise a supersaturated bainitic ferrite lath of thickness $w_{\alpha}$ is given by [12]:

$$
t_{d}=\frac{w_{\alpha}^{2} \pi\left(\bar{x}-x^{\alpha \gamma}\right)^{2}}{16 \bar{D}\left(x^{\gamma \alpha}-\bar{x}\right)}
$$

where: $\bar{x}$ is the average carbon concentration in the alloy, $x^{\alpha \gamma}$ and $x^{\gamma \alpha}$ are the carbon concentrations in ferrite and austenite respectively, when the two phases are in paraequilibrium.

The calculated diffusion coefficient of carbon sharply decreases with temperature (Table 2). 
Table 2. The calculated diffusion coefficients of carbon in austenite $D\{x\}$ and a weighted average diffusivity $\bar{D}$ after austenitisation at 950 and $830^{\circ} \mathrm{C}$ and austempering at 400 and $350^{\circ} \mathrm{C}$

\begin{tabular}{|l|l|l|}
\hline$T_{i},{ }^{\circ} \mathrm{C}$ & \multicolumn{1}{|c|}{$D\left[\mathrm{~m}^{2} / \mathrm{s}\right]$} & $\bar{D}\left[\mathrm{~m}^{2} / \mathrm{s}\right]$ \\
\hline \multicolumn{3}{|c|}{ Austenitisation temperature, $T \gamma=950^{\circ} \mathrm{C}$} \\
\hline 400 & $0.3574 \times 10^{-15}$ & $0.1672 \times 10^{-14}$ \\
\hline 350 & $0.4688 \times 10^{-16}$ & $0.5013 \times 10^{-15}$ \\
\hline 300 & $0.4328 \times 10^{-17}$ & $*$ \\
\hline 250 & $0.2544 \times 10^{-18}$ & $*$ \\
\hline \multicolumn{3}{|c|}{ Austenitisation temperature, $T \gamma=830^{\circ} \mathrm{C}$} \\
\hline 400 & $0.2088 \times 10^{-15}$ & $0.1427 \times 10^{-14}$ \\
\hline 350 & $0.2714 \times 10^{-16}$ & $0.4287 \times 10^{-15}$ \\
\hline 300 & $0.2482 \times 10^{-17}$ & $*$ \\
\hline 250 & $0.1445 \times 10^{-18}$ & $*$ \\
\hline
\end{tabular}

* Diffusion calculation outside of permitted range. Siller-McLellan model fails at high carbon concentrations evaluate $\bar{D}$.

The calculated times of partitioning are shown in Fig. 5 for different thickness of bainitic ferrite phase (for $w_{o}=0.1,0.2,0.5,1.0,10,50$, and $100 \mu \mathrm{m}$ ) and austenitising and austempering temperatures. For investigated ductile cast iron ADI our calculations show that $t_{d}$ increases sharply as temperature decreases.

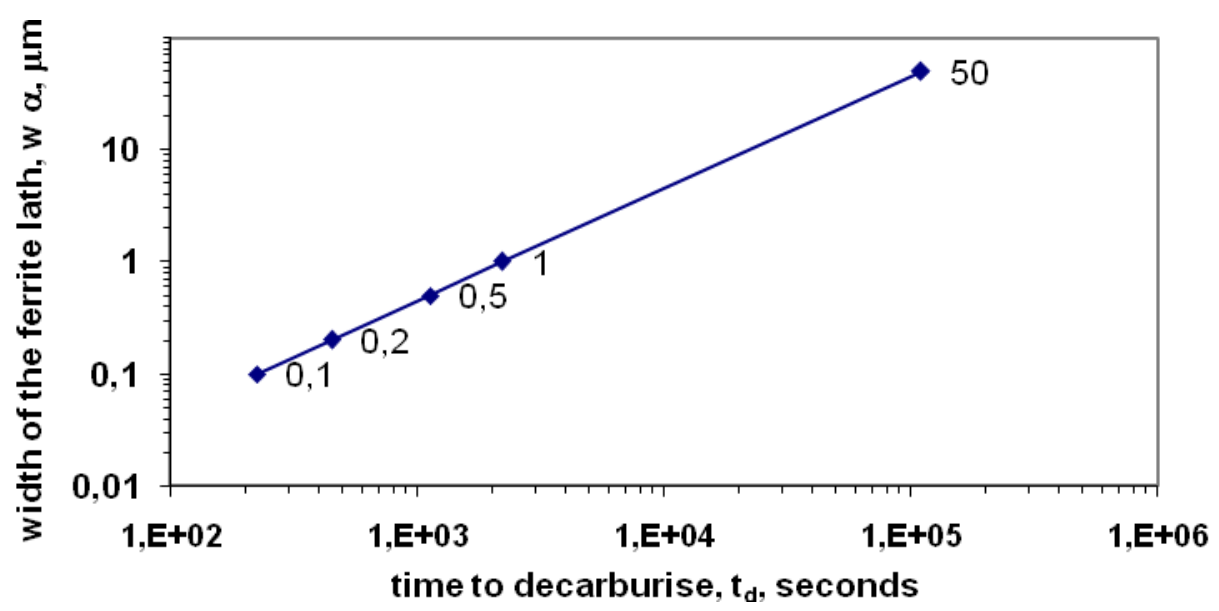

Fig. 5. The calculated decarburisation times for a given width of ferrite phase in investigated ADI

The decarburisation time $t_{d}$ is a function of $\alpha$ phase width and increases with decreasing austempering temperature. The decarburisation time also increases as the thickness of the ferrite phase and austenitising temperature increases (Fig. 6). 


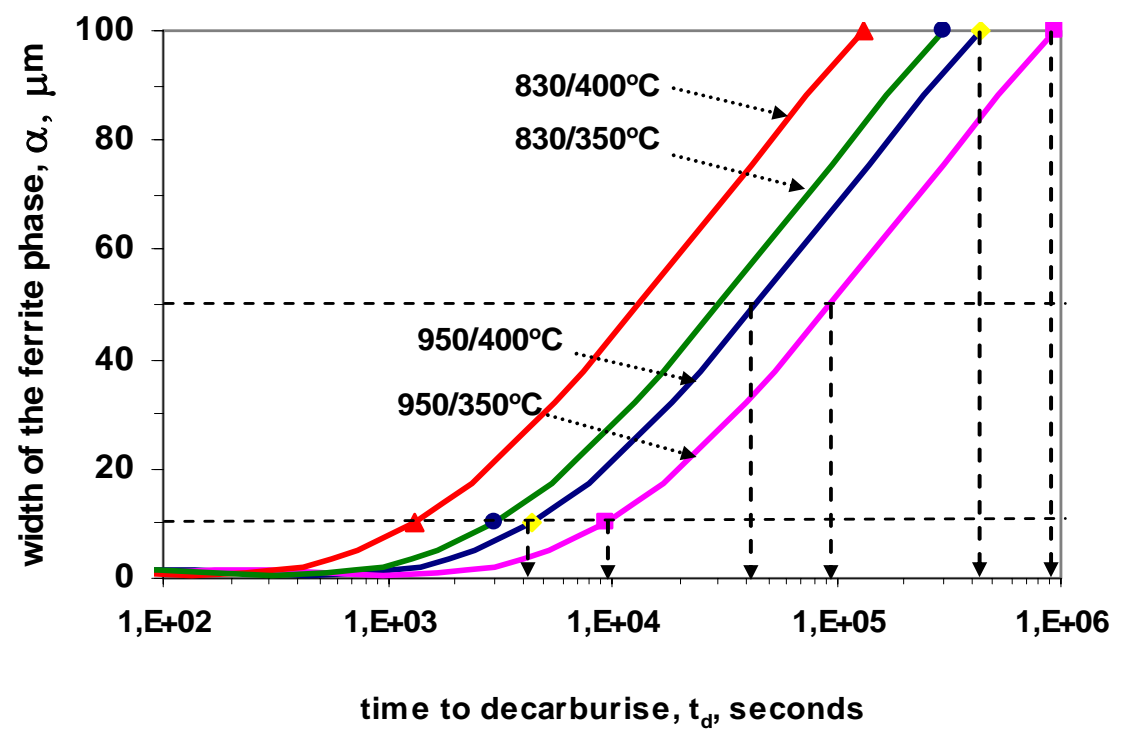

Fig. 6. The calculated decarburisation times for a given width of ferrite phase in investigated ADI after austenitisation at 950 and $830^{\circ} \mathrm{C}$ and austempering at 400 and $350^{\circ} \mathrm{C}$. The relationship (6) has been used for calculations

Furthermore, it is generally observed that the width of ferrite laths is highly diverse. This reflect the possibility that cementite can precipitate in thicker bainite laths (when $t_{d}$ is a long period of time) and in thinner laths has not during isothermal transformation. It is also consistent with the fact that upper and lower bainite often form at the same temperature in a given steel or ductile iron $[5,6,17,18]$. Thus, the calculated average carbon diffusion distances over specific periods of time $(100,1000$ and $10000 \mathrm{~s})$ are shown in Table 3.

Table 3. The calculated average carbon diffusion distances $z$ after 100, 1000 and 10000 seconds during austempering at 400 and $350^{\circ} \mathrm{C}$ after austenitisation at 950 and $830^{\circ} \mathrm{C}$

\begin{tabular}{|c|c|c|c|}
\hline \multirow{2}{*}{$T \gamma, 950^{\circ} \mathrm{C}$} & \multicolumn{3}{|c|}{ Carbon diffusion distances } \\
& \multicolumn{3}{|c|}{$\mathrm{z}=2 \sqrt{\bar{D} t}, \mathrm{~m}$} \\
\hline & \multicolumn{3}{|c|}{ for time, $\mathrm{t}$, seconds } \\
\hline $\mathrm{Ti},{ }^{\circ} \mathrm{C}$ & 100 seconds & 1000 seconds & 10000 seconds \\
\hline 400 & $8.178 \times 10^{-7}$ & $25.861 \times 10^{-7}$ & $81.78 \times 10^{-7}$ \\
\hline 350 & $44.779 \times 10^{-8}$ & $141.605 \times 10^{-8}$ & $447.794 \times 10^{-8}$ \\
\hline & \multicolumn{3}{|c|}{ Carbon diffusion distances } \\
$T \gamma, 830^{\circ} \mathrm{C}$ & \multicolumn{3}{|c|}{$\mathrm{z}=2 \sqrt{\bar{D} t}, \mathrm{~m}$} \\
\hline & \multicolumn{3}{|c|}{ for time, $\mathrm{t}, \mathrm{seconds}}$, \\
\hline $\mathrm{Ti},{ }^{\circ} \mathrm{C}$ & 100 & 1000 & 10000 \\
\hline 400 & $7.555 \times 10^{-7}$ & $23.891 \times 10^{-7}$ & $75.551 \times 10^{-7}$ \\
\hline 350 & $41.410 \times 10^{-8}$ & $130.950 \times 10^{-8}$ & $414.101 \times 10^{-8}$ \\
\hline
\end{tabular}




\section{CONCLUSIONS}

The paper presents an investigation of the decarburisation of bainite laths and carbon diffusion distances in the matrix of ADI during bainitic reaction. The following conclusions were reached:

1. A consequence of the necessity of cementite precipitation from ferrite or/and austenite during austempering is that the resulting microstructure is not an ausferrite but is a mixture of bainitic ferrite, retained austenite and carbides.

2. The necessary carbon diffusion distance in austenite also illustrates that the estimated time is not capable of decarburising the ferrite laths during the period of austempering.

3. Analytical calculations of the time required for the diffusion of carbon out of supersaturated laths of ferrite into the retained austenite indicate that there is a necessity of carbides precipitation from ferrite.

4. The bainite transformation in cast iron is essentially identical to that in steel. In steel, it has been demonstrated that the carbon concentration of the residual austenite reaches the critical value represented by the $T_{0}$ curve will render the displacive bainite reaction to cease. Therefore the carbon concentration of austenite can be estimated by the thermodynamics principles described here.

\section{REFERENCES}

1. Chang L.C.: Carbon content of austenite in austempered ductile iron. Scripta Materialia. 39 (1998), 35-38.

2. Pietrowski S.: Nodular cast iron of bainitic ferrite structure with austenite or bainitic structure. Archives of Materials Science. 18 (1997), 253-273. (in Polish)

3. Guzik S.E.: Austempered cast iron as a modern constructional material. Inżynieria Materiałowa. 6 (2003), 677-680. (in Polish).

4. Ławrynowicz Z., Dymski S.: Analysis of carbon diffusion during bainite transformation in ADI. Archives of Foundry Engineering. 7 (2007), 87-92.

5. Takahashi M., Bhadeshia H.K.D.H.: A Model for the Microstructure of Some Advanced Bainitic Steels. Materials Transaction. JIM. 32 (1991) 689-696.

6. Lawrynowicz Z.: Transition from upper to lower bainite in Fe-Cr-C steel. Materials Science and Technology. 20 (2004), 1447-1454.

7. Lawrynowicz Z.: A discussion on the mechanism of bainite transformation in steels. Technology and Materials. Gdańsk. Politechnika Gdańska. 4 (2006), 149-155 (in Polish).

8. Lawrynowicz Z.: Mechanism of bainite transformation in Fe-Cr-Mo-V-Ti-C steel. International Journal of Engineering. 12 (1999), 81-86.

9. Christian J.W.: Theory of transformations in metals and alloys, 778, Oxford, Pergamon Press, 1965.

10. Bhadeshia H.K.D.H.: Bainite in Steels. Institute of Materials. 1-458, London, 1992.

11. Kinsman K.R., Aaronson H.I., The transformation and hardenability in steels, Climax Molybdenum Company, Ann Arbor, MI, p.39, 1967. 
12. Bhadeshia H.K.D.H., Christian J.W.: Bainite in Steels. Metallurgical Transactions A. 21A (1990), 767-797.

13. H.K.D.H. Bhadeshia: Diffusion of carbon in austenite. Metal Science. 15 (1981), 477-479.

14. Siller R.H., McLelan R.B.: The Application of First Order Mixing Statistics to the Variation of the Diffusivity of Carbon in Austenite. Metallurgical Transactions. 1 (1970), 985-988.

15. Ławrynowicz Z.: Criticism of selected methods for diffusivity estimation of carbon in austenite. Zeszyty Naukowe ATR. nr 216, Mechanika 43 (1998), 283-287. (in Polish).

16. Lawrynowicz Z.: Bainitic transformation: estimation of carbon diffusivity in austenite on the basis of measured austenite film thickness. Zeszyty Naukowe ATR. nr 216 Mechanika 43, (1998) 289297. (in Polish).

17. Ławrynowicz Z.: A discussion on the mechanism of bainite transformation in steels. Technology and Materials. Gdańsk, Politechnika Gdańska. 4, (2006), 149-155. (in Polish)

18. Lawrynowicz Z.: Observation of interphase boundary: bainite-non-pearlitic eutectoid in Cr-Mo-C alloy by TEM. Technology and Materials. Gdańsk, Politechnika Gdańska. 4 (2006), 156-160. (in Polish) 